\title{
Philanthropy and the For-profit Corporation: The Benefit Corporation as the New Form of Firm Altruism
}

\author{
Livia Ventura ${ }^{1,2,3,4}$
}

Accepted: 2 November 2021 / Published online: 11 January 2022

(c) T.M.C. Asser Press 2021

\begin{abstract}
Currently the issue of sustainability is at the heart of the debate on corporate governance of business companies. In Europe, an intense activity of revising and updating European rules applicable to financial markets and company law has started. In Italy, such debate became more intense after the legal transplant of the US benefit corporation model in late 2015. The Italian società benefit allows, through a voluntary choice of the founding members or the shareholders' meeting, to internalise values typical of corporate social responsibility in the articles of association, making them legally binding on the company and the directors. Considering the traditional dichotomy between for-profit entities and non-profit entities, hybrid models such as the benefit corporation appear to struggle in finding an adequate space within capitalist systems and corporate governance theories. This study attempts to offer an interpretative key for understanding these hybrid models, abandoning the classical homo economicus paradigm to embrace a reading based on behavioural law and economics and the Yale approach to economic analysis of law, according to which altruism and beneficence should be considered as ends in themselves, as goods desired by people and for which they are willing to pay a price. In this line of reasoning, benefit corporations and other hybrid models, because of their ability to bring altruistic values into the corporate purpose, departing from shareholder value maximisation as the raison d'être of the corporate form, can be considered as a further manifestation of 'firm altruism', given that they are characterised by a deep and lasting impact on the environment and civil society.
\end{abstract}

Keywords Benefit corporation · Firm altruism · Altruism · Corporate philanthropy · Società benefit . Corporate governance

Livia Ventura

lventura@luiss.it

Extended author information available on the last page of the article 


\section{Introduction}

Public interest and, more generally, 'altruistic' interests have been traditionally pursued by the state and non-profit entities. In the last decades, their effort has been supplemented by the activity of for-profit companies as part of their corporate social responsibility (CSR) programs and, in particular, their corporate philanthropy programs.

Nowadays, under the pressure of international organisations, ${ }^{1}$ the issue of sustainability is not just at the heart of the political agenda of governments around the world but also at the centre of the debate on corporate governance of business companies due to the recognition of their essential role in the creation of equitable and sustainable economic growth.

Looking at the Western legal systems, over the past few decades, the United States, responding to the discussion on businesses' sustainability, has seen the birth of new 'hybrid' organisational forms, capable of bringing together social and environmental aims with the business approach. ${ }^{2}$ Among them, the most widespread is the benefit corporation, ${ }^{3}$ which is reflected in more comprehensive legislation and which is currently enacted by 37 US jurisdictions. Actually, the political and legal debate over new forms of 'stakeholder capitalism' continues to be fervent. ${ }^{4}$ For instance, in August 2018, Senator Elizabeth Warren introduced the bill for the 'Accountable Capitalism Act', 5 which would require every corporation with more than $\$ 1$ billion in annual revenue to become federally chartered as a 'United States corporation' and to essentially adopt a model similar to that of a benefit corporation. ${ }^{6}$

\footnotetext{
1 E.g., see the United Nations 2030 Agenda for Sustainable Development and its SDGs (UN General Assembly, Transforming our world: the 2030 Agenda for Sustainable Development, 21 October 2015, A/ RES/70/1).

2 E.g., the Low-Profit Limited Liability Company (L3C) introduced for the first time in Vermont in 2008 (Vt. Stat. Ann. Tit. 11, § 3001(27)) and then in other states such as Illinois, Louisiana, Maine, Michigan, Rhode Island, Utah, and Wyoming; or the Social Purpose Corporation (SPC) introduced in California in 2011 (formerly known as the flexible purpose corporation, Cal. Corp. Code $\$ \S 2513,2602$ (b)./25002517), then in Washington in 2012, and in Florida in 2014.

3 The first benefit corporation statute was passed in Maryland in 2010, see Md. Code Ann., Corps. \& Ass'ns $§ 5-6 C$.

4 For an analysis of the debate from the legal and political perspective, see Rock (2020).

5 See the Accountable Capitalism Act, S.3348, 115th Congress (2017-2018). Other policy proposals of a similar nature have been sustained by Democratic Senator Bernie Sanders, proposing to shift the wealth of the economy back into the hands of the workers, giving them an ownership stake in the companies they work for (further information is available at https://berniesanders.com/issues/corporate-accountabi lity-and-democracy/ (accessed 27 October 2021), as well as by Republican Senator Marco Rubio, whose report 'American Investment in the twenty first century: project for strong labor markets and national development' criticises the shareholder primacy theory (further information can be found at https://www. americanmoment.org/american-investment-21st-century/ (accessed 27 October 2021).

6 Indeed, these chartered corporations, similarly to the benefit corporation, shall have the purpose of creating a 'general public benefit' and directors shall have the duty to balance the pecuniary interests of the shareholders with the best interests of persons that are materially affected by the conduct of the corporation (such as employees, customers, the communities and the environment). Moreover, the bill empowers workers to elect at least two fifths of the board of directors' members and restricts the sales of company shares by directors and officers to ensure they are focused on the long-term interests of all corporate stakeholders.
} 
In Europe, the growing importance of sustainability and its perception as an added value for profit-making companies has triggered an intense activity of revising and updating the European rules applicable to financial markets and company law. In particular, from the initial promotion of voluntary CSR programs through the development of soft law instruments such as the European Strategy on Corporate Social Responsibility, ${ }^{7}$ the focus has shifted to the introduction of mandatory rules encouraging the adoption of sustainable business practices. This includes the Directive on non-financial reporting, ${ }^{8}$ the Directive on the encouragement of longterm shareholder engagement, ${ }^{9}$ the Regulation on sustainability-related disclosure in the financial services sector, ${ }^{10}$ and the recent Regulation on the establishment of a framework to facilitate sustainable investment. ${ }^{11}$ Moreover, a directive on supply chain due diligence ${ }^{12}$ as well as one on directors' duties and sustainable corporate governance $^{13}$ are currently under consideration by the EU institutions.

Regarding the latter, the preparatory study on directors' duties and sustainable corporate governance commissioned by the European Commission (the 'EY Study' $)^{14}$ has been strongly criticised by famous corporate law scholars for, amongst

\footnotetext{
7 See, e.g., the Green Paper 'Promoting a European framework for corporate social responsibility', 18.7.2001, $\operatorname{COM(2001)~366;~Commission~Communication~of~} 15$ May 2001 'A sustainable Europe for a better world: a European Union strategy for sustainable development', COM(2001) 264; Commission Communication of 13 December 2005 'on the review of the Sustainable Development Strategy-a platform for action', $\operatorname{COM(2005)~658;~Commission~Communication~of~} 25$ October 2011 on 'a renewed EU strategy 2011-14 for Corporate Social Responsibility', COM(2011) 681.

8 Directive 2014/95/EU of the European Parliament and of the Council of 22 October 2014 amending Directive 2013/34/EU as regards disclosure of non-financial and diversity information by certain large undertakings and groups ('the Non-Financial Reporting Directive'). See also the recent Proposal for a Directive amending Directive 2013/34/EU, Directive 2004/109/EC, Directive 2006/43/EC and Regulation (EU) No 537/2014, as regards corporate sustainability reporting, of 21 April 2021, COM(2021) 189, 2021/0104 (COD), reviewing the Non-Financial Reporting Directive.

${ }^{9}$ Directive (EU) 2017/828 of the European Parliament and of the Council of 17 May 2017 amending Directive 2007/36/EC as regards the encouragement of long-term shareholder engagement.

10 Regulation (EU) 2019/2088 of the European Parliament and of the Council of 27 November 2019 on sustainability-related disclosures in the financial services sector.

11 Regulation (EU) 2020/852 of the European Parliament and of the Council of 18 June 2020 on the establishment of a framework to facilitate sustainable investment, and amending Regulation (EU) 2019/2088 (the 'EU Taxonomy Regulation'). See also Commission Communication of 21 April 2021 on 'EU taxonomy, corporate sustainability reporting, sustainability preferences and fiduciary duties: directing finance towards the European Green Deal', COM(2021) 188.

12 See the Study on due diligence requirements through the supply chain: final report (2020), published on 20 February 2020, available at https://op.europa.eu/en/publication-detail/-/publication/8ba0a8fd4c83-11ea-b8b7-01aa75ed71a1/language-en (accessed 27 October 2021); and European Parliament resolution P9_TA(2021)0073 of 10 March 2021 with recommendations to the Commission on corporate due diligence and corporate accountability (2020/2129(INL).

13 See the Study on directors' duties and sustainable corporate governance: final report (2020), published on 29 July 2020, available at https://op.europa.eu/en/publication-detail/-/publication/e47928a2d20b-11ea-adf7-01aa75ed71a1/language-en [hereinafter the EY Study] (accessed 27 October 2021).

14 Ibid. The EY Study identifies several policy proposals to foster the development of sustainable corporate governance and sustainable value creation, including: extension of directors' duties to include the interests of stakeholders, increase in long-term shareholders' voting rights, the need for sustainability planning and disclosure, tying executive compensation to sustainability metrics, considering sustainability in board nominations, requiring mechanisms for engaging with stakeholders in dealing with sustain-
} 
others, failing to define the problem correctly and address the relevant academic research. ${ }^{15}$ Leaving aside the various criticisms of the study and its regulatory proposals, which also comprise the integration of sustainability into the business strategy and the extension of directors' duties to include the interests of stakeholders other than shareholders, what is relevant here is that the issue of businesses' sustainability is currently at the heart of the corporate law debate at the European level.

In Italy, such debate became more intense after the legal transplant of the US benefit corporation model in late $2015 .{ }^{16}$ The Italian società benefit hybrid model, like the benefit corporation model, allows, through a voluntary choice of the founding members or the shareholders' meeting, to internalise values typical of corporate social responsibility in the articles of association (in the company's purpose clause), making them legally binding on the company and the directors. The direct consequence of this is the integration of sustainability aspects into the business strategy (as also proposed by the EY Study ${ }^{17}$ ) and the company's commitment to creating not only value for its shareholders but also shared value, or so-called public benefit ('beneficio comune'). ${ }^{18}$

Similar hybrid models have been introduced in other countries, such as in Latin America, in particular Colombia, Ecuador and Peru ('Sociedades de Beneficio e

Footnote 14 (continued)

ability risks, and allowing stakeholders to bring suits in courts for alleged violations by directors of the duty of care and loyalty.

15 See Roe et al. (2020). The article criticises the EY Study because, according to the authors: (i) it fails to define the problem properly (focusing only on short-termism as the main corporate governance problem without taking into consideration other aspects such as negative externalities and distributional concerns); (ii) it presents inapposite evidence (focusing on rising gross payouts to shareholders while the more relevant payout measure to assess corporations' ability to fund long-term investment is net payouts); (iii) it fails to address the relevant academic research (only picking studies supporting its views on short-termism); and (iv) it neglects problems with its policy proposals.

16 Law No. 208, 28 December 2015 (G.U. 30.12.2015), 'Disposizioni per la formazione del bilancio annuale e pluriennale dello Stato (Legge di Stabilità 2016)', Art. 1, paras. 376-384.

17 See the EY Study, at pp 94-95.

18 The Italian legislator decided not to amend the general regulations governing commercial companies provided in the Civil Code (unlike in France with the Loi PACTE, Law No. 2019-486 of 22 May 2019, Art. 169) but preferred to extend the freedom of entrepreneurs to engage in private ordering of their business affairs by offering a further choice among the existing organisational options. The introduction of the società benefit statute, however, triggered an intense doctrinal debate on whether ordinary business companies can consider the interests of stakeholders other than shareholders (e.g., for a debate on the issue, please refer to De Donno and Ventura (2018), and in particular to the essays by Angelici (2018), pp 24-25; Denozza (2018), pp 46-48, Marasà (2018), pp 53-58 and Stella Richter (2018), pp 60-65). According to an interpretation within the spirit of the law (which is to promote the pursuit of altruistic purposes of public benefit) it is possible to affirm that the società benefit statute should not be understood as prohibiting ordinary companies from carrying out entrepreneurial activities in ways that also serve purposes of common benefit. Ordinary companies may also pursue altruistic purposes of public benefit (by means of socially responsible management of the business activity, or by allocating part of the distributable profits to such purposes), provided that the management choices and/or disbursements for purposes of common benefit are not of such a nature and/or extent as to compromise the achievement of the economic purpose constituting the 'cause' (the 'causa', intended as an essential feature of the contract according to Italian law) of the company’s agreement (see Marasà (2018), p 54). 
Interés Colectivo'), in British Columbia (Canada) ('benefit company'), and in France ('entreprise à mission'), while bills are pending introduction in several countries. ${ }^{19}$

From a European perspective, the path followed by the Italian and French legal systems seems to be consistent with the recent European Union initiatives aimed at a more comprehensive protection of stakeholders' interests in for-profit entities and at fostering the development of sustainable corporate governance.

Considering the traditional dichotomy between the pursuit of self-interest purposes by for-profit entities on the one side, and the pursuit of altruistic purposes by non-profit entities on the other, hybrid models entering the emerging fourth sector of the economy, such as the benefit corporation, appear to struggle in finding an adequate space within capitalist systems and corporate governance theories.

This study attempts to offer an interpretative key for understanding these hybrid models, abandoning the classical homo economicus paradigm to embrace a reading based on behavioural law and economics and the Yale approach to economic analysis of law, according to which altruism and beneficence should be considered as ends in themselves, as goods desired by people and for which they are willing to pay a price.

In this line of reasoning, benefit corporations and other hybrid models, because of their ability to bring altruistic values into the corporate purpose, departing from shareholder value maximisation as the raison d'etre of the corporate form, can be considered as a further manifestation of 'firm altruism', given that they are characterised by a deep and lasting impact on the environment and civil society.

\section{The Dichotomy Between For-profit and Non-profit Entities: Self-Interest Purpose v. Altruistic Purpose}

In 1759, Adam Smith, in his first book 'The Theory of Moral Sentiments', stated:

How selfish soever man may be supposed, there are evidently some principles in his nature, which interest him in the fortunes of others, and render their happiness necessary to him, though he derives nothing from it, except the pleasure of seeing it. ${ }^{20}$

It is interesting to note how the author who is considered the father of modern economics and capitalism and whose philosophy is based on the concepts of selfinterest and maximising return, discussed the existence of charity, human ethics, and beneficence (or altruism). ${ }^{21}$

\footnotetext{
19 See, e.g., Argentina (Bill No. 2498-D-2018, approved by the Cámara de Diputados in December 2018, which is pending approval in the Senado) and Chile (Bill No. 11273-03, of May 2017). It is worth noting that at the beginning of 2021 Rwanda passed the benefit corporation legislation, introducing the so-called 'community benefit company' and becoming the 6th country in the world to provide this option, see Chapter XIII 'Community Benefit Company', Arts. 269-273 of Law N 007/2021, of 5 February 2021 (Official Gazette ${ }^{\circ} 04$ ter of 08/02/2021).

20 Smith (1759), Part I, Section I, p 2.

21 Khalil (2001), p 421.
} 
From the economic theory perspective, the business corporation developed in capitalist systems on the one hand, and the concept of altruism on the other, seemprima facie - to belong to sharply contrasting spheres, especially if one looks at the birth of the business corporation and its traditional function.

Business corporations are organisations whose primary goal is to jointly carry out an economic activity with the aim of making a profit (so-called objective profit) and to distribute the earnings among the owners of the enterprise (so-called subjective profit). ${ }^{22}$

Currently, the predominant model accepted by corporate law in the major legal systems belonging to the Western legal tradition is the 'shareholder primacy' model, ${ }^{23}$ even though the pursuit of some form of 'public interest' was one of the core elements of business corporations since their birth as chartered companies. ${ }^{24}$

The development of the modern corporate governance debate stemmed from the dialogue between Dodd and Berle in the thirties of the nineteenth century, in which are rooted the opposite models of 'stakeholder primacy' (based on the assumption that directors have to balance the interests of all constituents of companies and behave in a socially responsible manner) and 'shareholder primacy' (based on the assumption that directors should run the company in the sole interest of shareholders). ${ }^{25}$

The contractarian theory of corporate law proposed by, among others, Berle and Means ${ }^{26}$ has prevailed and, notwithstanding the birth of new theories such as

\footnotetext{
${ }^{22}$ This perspective is encompassed by the definitions of for-profit companies offered by several civil or commercial codes in countries with a Western legal tradition, such as that contained in Art. 2447 of the Italian Civil Code, according to which '[c]on il contratto di società due o più persone conferiscono beni o servizi per l'esercizio in comune di un'attività economica allo scopo di dividerne gli utili' ('[w]ith the company's contract, two or more persons contribute assets or services in order to jointly conduct an economic activity and pursue the purpose of sharing the profits thus gained'); or Art. 1832 of the French Civil Code, according to which 'La société est instituée par deux ou plusieurs personnes qui conviennent par un contrat d'affecter à une entreprise commune des biens ou leur industrie en vue de partager le bénéfice ou de profiter de l'économie qui pourra en résulter' ('A firm is established by two or several persons which agree by a contract to appropriate property or their industry for a common venture with a view to sharing the benefit or profiting from the saving which may result therefrom.').

${ }^{23}$ Among many, see Hansmann and Kraakman (2001), pp 440-441, according to which ' $[\mathrm{t}] \mathrm{here}$ is no longer any serious competitor to the view that corporate law should principally strive to increase longterm shareholder value.'; and see the historical analysis and original descriptive account of the United States 'corporate governance machine' as a complex governance system composed of law, markets, and culture that orients corporate decision-making towards shareholder primacy proposed by Lund and Poll$\operatorname{man}(2021)$.

${ }^{24}$ Williston (1888), pp 105, 109-112.

${ }^{25}$ See Berle (1931), p 1049 et seq. (affirming that managers should pursue only the shareholders' interest); Dodd (1932), p 1145 et seq. (affirming that the corporation, as an institution, also has a public benefit purpose); Berle (1932), p 1365 et seq. (the author stressed his original position and affirmed that the managers of a corporation are only responsible towards the shareholders). On the issue see Bratton and Wachter (2008), p 99 et seq. On the evolution of Berle's thought see Berle (1954), p 169; Berle (1959), pp ix, xii; Bainbridge (2003), p 561, note 70. The debate between Dodd and Berle has recently been re-opened in the discussions related to corporate social responsibility, see Sommer (1991), p 33 et seq.; Harwell Wells (2002), p 77 et seq.

${ }^{26}$ Berle and Means (1932).
} 
stakeholderism, ${ }^{27}$ communitarianism ${ }^{28}$ or the enlightened shareholder value, ${ }^{29}$ the shareholder primacy mode ${ }^{30}$ has become the most widespread corporate governance regime. Moreover, the growth of the role of the capital market in the economy and the consequent financialisation of corporate law have strengthened the paradigm of the maximisation of shareholder value (MSV) as the fundamental objective of business activity.

Therefore, business corporations are characterised by a self-interest purposematerialised in the maximisation of profits and their distribution to the shareholders - which is antithetical to altruism, intended as any behaviour designed to increase another person's welfare and which does not seem to provide a direct reward to the person who performs such behaviour. ${ }^{31}$

Looking at the empirical reality through the lens of the economic analysis of law (EAL), it can be observed that the self-interest model of the business corporation sticks perfectly to the homo economicus paradigm of neoclassical economics according to which human beings are rational and selfish actors, focused entirely on maximising their own material well-being. ${ }^{32}$

Nonetheless, the empirical evidence demonstrates the existence, in fact, of altruism and beneficence, as well as that of other organisational forms-the non-profit entities - which are characterised by an altruistic purpose (i.e., the reinvestment of profits into the specific public benefit pursued) and a typical structure based on the non-distribution constraint. ${ }^{33}$

The observation of reality shows that the unselfish prosocial behaviour, which seems to depart from the homo economicus model and the rational choice theory, is very common in human social life (as also demonstrated by several social dilemma experiments). ${ }^{34}$

\footnotetext{
${ }^{27}$ Among the pioneering works on the issue, see Mitroff (1983); Freeman and Reed (1983), p 89 et seq.; and Freeman (1984).

${ }^{28}$ The term 'communitarianism', borrowed from Amitai Etzioni's communitarian thesis which stressed the importance of moral, social, and political foundations of society, is here used to indicate those company law scholars who criticise the contractarian theory, see Millon (1993), pp 1378-1381; DeBow and Lee (1993), pp 395-397.

${ }^{29}$ See Collison et al. (2014), pp 5-16.

${ }^{30}$ Friedman (1970). See also Bebchuk (2003), p 43 et seq.; Bebchuk and Fried (2005), p 647 et seq.; Bebchuk (2005), p 833 et seq.; Bebchuk and Fried (2006); Bebchuk (2006), p 1784 et seq.

${ }^{31}$ See Batson et al. (2011), p 103 et seq.; Dovidio et al. (2006); Penner et al. (2005), p 365 et seq.

${ }^{32}$ On the homo economicus model see Stout (2014), pp 195-212.

${ }^{33}$ On this issue see Hansmann (1980), p 835 et seq.; Hansmann (1981), p 501 et seq.

${ }^{34}$ Stout (2014), pp 198-200.
} 


\section{Altruism as an 'End in Itself'}

Once we accept the rational choice theory (according to which individuals build their choices through a cost-benefit analysis with a view to maximising the utility expected by them $)^{35}$ as well as the conception of the individual as a 'maximising individual' that is typical of neoliberalism, ${ }^{36}$ it appears difficult to justify those human conducts that are led by altruistic and disinterested behaviours. Consequently, unselfish actions of individuals are considered as a sort of deviation from the paradigm of rational behaviour. ${ }^{37}$

That being so, how to explain 'the daily dynamics of gratuitousness and selflessness, ${ }^{38}$ the existence of altruism, charity and not-for-profit organisations (seeing that for-profit companies are supposed to be more efficient, from the economic analysis of law perspective, in the production of goods and services) $?^{39}$ How to explain the existence of altruistic behaviour, looking at the phenomenon through the inflexible lenses of the economic analysis of law and the neoclassical economics that identify in the homo economicus the paradigm of the individual to be taken as normative model $?^{40}$

The observation of empirical reality therefore seems to suggest the need for rethinking the behavioural paradigm of the homo economicus, intended as the expression of the industrial revolution and utilitarianism, 'that cannot be universalised neither in space nor in time ${ }^{41}$ and that is not apt to explain the inclination towards altruism and cooperation that is, to the contrary, a fundamental and universal aspect of human behaviour, as much as selfish conduct and the pursuit of material well-being. ${ }^{42}$

In this sense, new behavioural models suitable for explaining the physical and juridical world can be found in the studies of behavioural law and economics, aimed at highlighting the cognitive variables within the decision-making processes of individuals ${ }^{43}$ and the reasons underlying human behaviours, ${ }^{44}$ as well as in the

\footnotetext{
35 See Friedman (1953), p 15 et seq.; Hargreaves Heap and Varoufakis (1995); Posner (1998), p 3; Ulen (2000), pp 790-791; Shavell (2004), p 1.

36 For further reading on this point see Denozza (2014), pp 13-47.

37 Resta (2014), pp 121-122, 135.

38 In this sense see Resta (2014), pp 122-123, specifically note 7, where the author mentions the debate on the 'overall deadweight loss on Christmas presents'.

39 In this regard see Calabresi (2016), pp 90-91, specifically notes 1, 2 and 3, p 204.

40 On this point see Gentili (2014), p 88 et seq.; Resta (2014), pp 132-133; Zoppini (2016), pp 14-15.

41 Citing Resta (2014), pp 134-135, who mentions, particularly at notes 60, 61 and 62, the criticisms by Amartya Sen, Ronald Coase and Karl Polanyi regarding the paradigm of the homo economicus.

${ }^{42}$ In this sense see Resta (2014), p 151; and for further reading on this matter see Solomon (1998), p 520 et seq.

43 See the studies by Simon (1955), p 99 et seq.; Simon (1957), p 270 et seq.; Kahneman and Tversky (1974), p 1124 et seq.; Kahneman and Tversky (1984), p 341 et seq.; Kahneman (2011). In general, on behavioural law and economics see Thaler (1996), p 227 et seq.; Sunstein (1997), p 1175 et seq.; Sunstein et al. (1998), p 1471 et seq.; Korobkin and Ulen (2000), p 1051 et seq.; Sustain (2000); Parisi and Smith (2005); Thaler and Sunstein (2008); Zamir and Teichman (2014).

44 Fehr and Gächter (2000a), p 159 et seq.; Fehr and Gächter (2000b), p 980 et seq.; Fehr and Fischbacher (2003), p 785 et seq.; Gintis et al. (2003), p 153 et seq.; Fehr and Schmidt (2006), p 615 et seq.
} 
'multi-faceted approach' to juridical phenomena that is typical of the Yale School of economic analysis of law (the so-called 'law \& economics'). ${ }^{45}$

With regard to the latter, an impressive starting point for the reconstruction of the phenomena of altruism and beneficence, useful for our purposes, is offered by a recent contribution of Guido Calabresi. ${ }^{46}$ According to this author, altruism, beneficence and similar values exist in the empirical reality not simply as 'means' for the production of goods and services, but also because they constitute 'ends in themselves', they are desired as 'goods in and of themselves' to satisfy the desire for which individuals are willing to pay a price ${ }^{47}$.

Hence, if we look at altruism and similar values as goods in and of themselves, desired by individuals, their existence cannot be deemed irrational merely because it does not correspond to the behavioural model of the homo economicus typical of the neoclassical economics.

Likewise, the existence of altruistic behaviours must not be deemed irrational only because they do not respond, according to the so-called McKean paradox, ${ }^{48}$ to the canonical structures of market and command employed in economic theory for the optimisation of production. ${ }^{49}$

In fact, if, on the one hand, the use of pure market or pure command incentives can destroy altruism or charity, ${ }^{50}$ there are, on the other hand, in the empirical reality, different forms of modified market and modified command that do not destroy charity and altruism, but quite the opposite, they are the most effective in optimising-indirectly - their production through the creation of a culture of altruism and the education in altruism. ${ }^{51}$

In his analysis of altruism, beneficence, and non-profit institutions, Calabresi also underlines how individuals' need for altruism as a good in and of itself ${ }^{52}$ shows

\footnotetext{
$\overline{45}$ In addition to Calabresi (2016), p 1 et seq., for a description of the approaches to the economic analysis of law of the schools of Yale (of law \& economics) - using economics to understand the law as it is in reality - and of Chicago (economic analysis of law) - using the economic paradigms to adjust the law, identifying the best choices in terms of efficiency, according to Pareto optimality - see the contribution by Alpa (2016), p 597 et seq., in particular pp 599-601. On this point see also Portale (2007), pp $145-146$.

46 Calabresi (2016), pp 90-116.

47 Calabresi (2016), pp 90-91.

48 See McKean (1975), pp 29-37; and Calabresi (2016), pp 92-93. On this matter an interesting insight is provided by the reflections on 'gratuitousness' and market by Bruni (2009), pp 164-165.

49 See Calabresi (2016), pp 92-95, and 105 et seq. The author, dealing with market and command incentives, resumes the concepts exemplarily illustrated by Coase (1937), pp 386-405, in which emphasis is put on the tension between price mechanism and vertical integration: on the one hand, the dynamic of free trade and, on the other, that of vertical command.

50 Buying altruism and charity on the market or imposing charity and altruism through a rigid system of prescriptions, instead of increasing their production, leads to their destruction, see McKean (1975), pp 29-30, and Calabresi (2016), pp 92-93.

51 Calabresi (2016), pp 94-97, 105 et seq.

52 It must be specified that, according to Calabresi, altruism does not constitute a single good, rather it constitutes a group of interrelated goods that can be placed on different levels: altruism as a meansreplaceable - for the production of other desired goods; and altruism as an end and good in and of itself, only partially replaceable depending on the type of desired altruism (private, public, or firm altruism), see Calabresi (2016), pp 94, 98 et seq.
} 
itself in several forms: the desire for individual altruistic behaviour (private altruism), altruistic behaviour by the state (public altruism) and altruistic behaviour by private firms (firm altruism). In this last case, it can take the form of not-for-profit companies and as philanthropic activity undertaken by for-profit companies. ${ }^{53}$

\section{Philanthropy and the For-profit Corporation}

From the perspective of for-profit companies, traditionally, the answer to the request for firm altruism has been 'corporate philanthropy' activities and programs.

According to accounting literature, philanthropy (or 'contribution') can be described as 'an unconditional transfer of cash or other assets to an entity or a settlement or cancellation of its liabilities in a voluntary nonreciprocal transfer by another entity acting other than as an owner', or as an 'unconditional promise to give' those assets in the future. ${ }^{54}$

Broadly speaking, corporate philanthropy consists in supporting beneficial causes and in achieving a positive social impact through contributions in cash or in kind (e.g., employee time, facilities, or products and services produced by the firm). In most cases, philanthropy results in financial contributions by companies to causes that are intended to promote the welfare of others and bring about social change. These donations can be handled directly by the company or through a foundation established and controlled by the company itself.

With the development of corporate social responsibility (CSR), philanthropy has now often become part of modern CSR programs.

In the past several decades, CSR has been the focus of the debate over the relationship between business and society. Dozens of definitions of corporate social responsibility have arisen since the 1950s. According to Carroll's famous four-part definition, CSR encompasses the economic, legal, ethical, and discretionary (philanthropic) expectations that society has of organisations at a given point in time, ${ }^{55}$ while philanthropy 'encompasses those corporate actions that are in response to society's expectation that businesses be good corporate citizens'. ${ }^{56}$

Notwithstanding the many attempts to define it, CSR remains an overarching concept. It can be described as a corporation's voluntary, self-regulatory initiative to assess and take responsibility for the company's effects on environmental and social well-being, going beyond law requirements.

CSR differs from traditional philanthropy because it goes a step further by directly involving the corporation's business model and business practices, in an effort to mitigate the potentially negative externalities resulting from the corporate

\footnotetext{
53 Calabresi (2016), pp 93-94.

54 See Statement of Financial Account Standards 116 (FASB116) issued by the Financial Accounting Standards Board in 1993, which is the primary guidance relating to the recording of contribution revenue by not-for-profit organisations.

55 Carroll (1979), p 500.

56 Carroll (1991), p 42.
} 
activity. What they share, is the possible positive impact on the organisation's brand image and the bottom line, ${ }^{57}$ as well as their voluntary nature.

\section{A New Desire for Firm Altruism}

In the last decade, especially due to the financial crisis, increased inequality, ethicsbased corporate scandals, and the rise of awareness of climate change risks, a profound reconsideration of the current economy and the capitalist system has begun, pointing to the need for a broader and deeper involvement of companies in generating a positive impact on the environment and society.

The failure of the dominant neoclassical economic paradigms and the need for rethinking the concepts of firm and entrepreneur are by now issues that are supported by many economists ${ }^{58}$ and that recall the ancient tradition of the Italian 'economia civile' developed by Vico and Genovesi in the eighteenth century. ${ }^{59}$

The idea of corporations not only as a tool for maximising shareholders' profits but also as an essential means for the resolution of social and environmental problems has spread, basically increasing and strengthening the demand for firm altruism.

Nowadays, many voices are supporting the cultural transition from the shareholders' capitalism model to a new form of stakeholders' capitalism. Among them, it is worth mentioning the proposals offered by the Catholic social doctrine through Pope Benedict's encyclical Caritas in veritate ${ }^{60}$ and Pope Francis' landmark encyclical Laudato sì ${ }^{61}$ in which the predominant paradigm of profit maximisation is placed in doubt in favour of an 'integral ecology' (namely environmental, economic, social and cultural) aimed at the protection of the common good. ${ }^{62}$

With regard to international institutions, it is important to mention the Tripartite Declaration of Principles Concerning Multinational Enterprises and Social Policy adopted by the International Labour Organisation, ${ }^{63}$ the UN Global Compact that supports companies committed to sustainable and socially responsible business practices, ${ }^{64}$ the UN 2030 Agenda for Sustainable Development and its 17

\footnotetext{
57 Godfrey (2005), pp 777-798.

58 An interesting perspective on the issue is offered by De Luca et al. (2010).

59 On the Italian 'economia civile' see Bruni and Zamagni (2015); Bruni (2009); Zamagni (2013), in particular p 117 et seq.

60 Pope Benedict XVI (2009).

61 Pope Francis (2015).

62 On the Encyclica Laudato si see also Toffoletto (2015), p 1203 et seq.

63 Adopted by the Governing Body of the International Labour Office at its 204th Session (Geneva, November 1977) and amended at its 279th (November 2000), 295th (March 2006) and 329th (March 2017) Sessions.

64 The UN Global Compact was officially launched at the UN Headquarters in New York City on 26 July 2000 .
} 
Sustainable Development Goals (SDGs), ${ }^{65}$ as well as the UN Addis Ababa Action Agenda of the Third International Conference on Financing for Development. ${ }^{66}$

As far as the European Union is concerned, the call for sustainability has been supported by the Europe 2020 strategy for smart, sustainable and inclusive growth, on the basis of which Member States must develop their policies, and which has recently been reiterated in the context of the recovery plan following the SARSCoV-2 pandemic, in particular in the Communication 'Europe's moment: repair and prepare for the next generation' of May $2020 .^{67}$

The increasing desire for firm altruism also seems confirmed by several market studies. ${ }^{68}$ In particular, people hold companies as accountable as governments for improving the quality of their lives, ${ }^{69}$ and the improvement of society is considered the first goal that every company should pursue according to a study conducted among millennials from 18 different countries. ${ }^{70}$

With regard to consumers, a growing number of them already align their purchases with their values and consider sustainability in their purchasing decisions. ${ }^{71}$ Investors, too, are increasingly interested in financing socially conscious businesses, see e.g., the BlackRock statement of February 2019 on sustainability as the future of investing. ${ }^{72}$ This has contributed to the growth of the socially responsible investing (SRI) movement, ${ }^{73}$ the emergence of specific stock markets and indices (such as the

\footnotetext{
65 See A/RES/70/1, Transforming our world: the 2030 Agenda for Sustainable Development, launched by a UN Summit in New York on 25-27 September 2015.
}

66 See A/RES/69/313, Addis Ababa Action Agenda of the Third International Conference on Financing for Development, adopted at the Third International Conference on Financing for Development (Addis Ababa, Ethiopia, 13-16 July 2015) and endorsed by the General Assembly in its resolution 69/313 of 27 July 2015.

67 Commission Communication of 27 May 2020 'Europe's moment: repair and prepare for the next generation', $\operatorname{COM}(2020) 456$.

68 See, among others, Ernst \& Young, 'Climate change and sustainability: seven questions CEOs and boards should ask about 'triple bottom line' reporting' (2010), pp 7-9; The 2010 Cone Cause Evolution Study, available at https://www.conecomm.com/2010-cone-communications-cause-evolution-study-pdf (accessed 27 October 2021). Among scholars see Grant (2012), pp 591-597; Kerr (2008), p 832 et seq.; Jackson (2010), p 92 et seq.

69 See Accenture, Havas Media RE:PURPOSE, The Consumer Study: From Marketing to Mattering. The UN Global Compact-Accenture CEO Study on Sustainability, available at https://webcache.googl eusercontent.com/search?q=cache:2tvcvHIRST4J:https://sustainability.glos.ac.uk/wp-content/uploads/ 2017/07/Accenture-Consumer-Study-Marketing-Mattering-2.pdf $+\& c d=1 \& \mathrm{hl}=\mathrm{it} \& \mathrm{ct}=\mathrm{clnk} \& \mathrm{gl}=\mathrm{it} \& \mathrm{cli}-$ ent=firefox-b-d, pp 7-8 (accessed 27 October 2021).

70 Deloitte, Millennial Innovation survey, January 2013 available at https://www2.deloitte.com/content/ dam/Deloitte/global/Documents/About-Deloitte/dttl-millennial-innovation-survey.pdf, p 9 (accessed 27 October 2021).

71 Accenture, Havas Media RE:PURPOSE, The Consumer Study: From Marketing to Mattering. The UN Global Compact-Accenture CEO Study on Sustainability, op. cit., pp 9-10; The 2010 Cone Cause Evolution Study, op. cit., p 5.

72 See The BlackRock Investment Institute, Sustainability: the future of investing, February 2019, showing how assets in dedicated sustainable investing strategies have grown at a rapid pace in recent years. On the issue, Reints (2019); Whelan and Kronthal-Sacco (2019).

73 See, e.g., the growth of the US responsible and impact investing movement, which has expanded to encompass about $33 \%$ of US investments, roughly $\$ 17.1$ trillion, as highlighted by the US SIF Foundation's 2020 Report on US Sustainable, Responsible and Impact Investing Trends, Executive Summary, available at https://www.ussif.org/files/Trends\%20Report\%202020\%20Executive\%20Summary.pdf (accessed 27 October 2021). 
Dow Jones Sustainability Indices and the Financial Times Stock Exchange 4Good), as well as the development of environmental, social and governance (ESG) criteria and sustainability assessment tools (such as the Global Impact Investing Rating System (GIIRS), the Global Reporting Initiative (GRI) Standards, the Sustainability Accounting Standards Board (SASB) standards, or the 'B Corp' certification issued by B Lab).

Even in the labour market, additional value is recognised by students and employees with regard to companies that can make a positive social and environmental impact. $^{74}$

Moreover, in the last years, the debate about corporate purpose and the "problem of shareholder primacy' has intensified among legal academics and business school professors, ${ }^{75}$ and the relevance of firm altruism has been recognised by the business community as well. In 2018, BlackRock CEO, Larry Fink, called for companies to, besides delivering financial performance, pursue a 'social purpose', make a positive contribution to society. ${ }^{76}$ And in August 2019, nearly 200 CEOs representing the largest US companies that are members of the Business Roundtable released a 'Statement on the Purpose of a Corporation', which moves away from shareholder primacy and includes a fundamental commitment to all of a company's stakeholders. ${ }^{77}$ Moreover, the 'Davos Manifesto 2020: The Universal Purpose of a Company in the Fourth Industrial Revolution', issued within the context of the World Economic Forum, affirmed that a company serves not only its shareholders, but all its stakeholders (employees, customers, suppliers, local communities, and society at large). ${ }^{78}$

The answer of the law to this stronger demand for firm altruism coming from civil society has been the introduction of new hybrid organisational forms characterised by a governance structure suitable for incorporating within the decision-making process altruism as a good in and of itself, as a new corporate purpose equivalent and complementary to the profit-making purpose.

Among several hybrid entity models, the most comprehensive and globally recognised is the benefit corporation model born in the United States in 2010.

\footnotetext{
74 See the 2010 Cone Cause Evolution Study, op. cit., pp 19-21; Net Impact's Talent Report: What Workers Want in 2012, available at https://www.netimpact.org/research-and-publications/talent-reportwhat-workers-want-in-2012 (accessed 27 October 2021); Clemente (2013), p 17; Montgomery and Ramus (2007).

75 With regard to the debate on corporate purpose see, e.g., Mayer (2017), p 157 et seq.; Mayer (2018); The British Academy (2019) The Future of the Corporation: Principles for Purposeful Business, available at https://www.thebritishacademy.ac.uk/publications/future-of-the-corporation-principles-for-purpo seful-business (accessed 27 October 2021); Bebchuk and Tallarita (2020), p 91 et seq.; Rock (2020); Lund and Pollman (2021).

76 See https://corpgov.law.harvard.edu/2018/01/17/a-sense-of-purpose/ (accessed 27 October 2021).

77 See the Business Roundtable statement, available at https://www.businessroundtable.org/businessroundtable-redefines-the-purpose-of-a-corporation-to-promote-an-economy-that-serves-all-americans (accessed 27 October 2021).

78 See https://www.weforum.org/agenda/2019/12/davos-manifesto-2020-the-universal-purpose-of-acompany-in-the-fourth-industrial-revolution/ (accessed 27 October 2021).
} 


\section{The Benefit Corporation}

Benefit corporations ${ }^{79}$ are for-profit corporations whose purpose, in addition to generating profits, is to reduce negative externalities and produce a positive impact on the environment, society, the workers and the community in which they operate (the so-called 'public benefit').

The first benefit corporation statute was passed in Maryland in 2010. Today, 36 US states plus Washington DC and Puerto Rico have passed benefit corporation statutes, the majority of which are inspired by the Model Benefit Corporation Legislation (Model Act) ${ }^{80}$ proposed by B Lab with the support of William H. Clark Jr. (Of Counsel at Drinker Biddle \& Reath LLP) and the American Sustainable Business Council. The most important exception is Delaware, which in 2013 introduced its own statute, the Public Benefit Corporation Act. ${ }^{81}$

Benefit corporations differ from traditional business corporations in entity purpose, directors' accountability and transparency, but not in taxation because they are subject to the same income tax rules provided for business corporations. ${ }^{82}$

The purpose of a benefit corporation is to create a 'general public benefit', which can be defined as a material positive impact on society and the environment ${ }^{83}$ assessed against a third-party standard. Moreover, a benefit corporation may, or must (depending on state law, such as Delaware), identify one or more 'specific public benefits' to pursue. ${ }^{84}$

\footnotetext{
${ }^{79}$ It is necessary to clarify that in this paper we are dealing with the benefit corporation legal model and not with the B Lab certification as 'benefit corporation' or 'B Corp', issued in accordance with the 'Benefit Impact Assessment' (BIA). The main difference between the legal model and the certification is that the B Corp Certification is a third-party certification administered by a non-profit organisation (B Lab) that can be acquired by any for-profit entity regardless of the organisational form used and the state of incorporation, while the legal model can be used only by companies incorporated in countries which implemented the model by statute and by the type of company authorised by the law (in Italy all types of company provided for by the law, while in the US only by corporations, with the exception of a few states, such as Delaware, authorising LLCs to acquire the 'for benefit' status).

${ }^{80}$ Available at http://benefitcorp.net/sites/default/files/Model\%20benefit\%20corp\%20legislation\%20_4_ 17_17.pdf (accessed 27 October 2021).

${ }^{81}$ See Subchapter XV of the Delaware General Corporation Law (Del. Code Ann. Tit. 8, §§ 361-368).

${ }^{82}$ See IRS Information Letter 2016-0063 of 2 June 2016, authorising benefit corporations to deduct contributions to charities as business expenses when the payments are for institutional or goodwill advertising to keep the corporation's name before the public. These contributions, which are treated as business expenses, essentially produce an immediate reduction in taxable income. As such, the IRS in fact provides for a tax advantage allowing benefit corporations to make donations or payments to charitable organisations greater than the current $10 \%$ limit on corporate charitable contributions.
}

${ }^{83}$ Model Act $§ 102$ - 'General public benefit' and § 201(a).

${ }^{84}$ See Model Act $\S \$ 102$ and 201(b), according to which the specific public benefit includes:

(1) providing low-income or underserved individuals or communities with beneficial products or services;

(2) promoting economic opportunity for individuals or communities beyond the creation of jobs in the normal course of business;

(3) protecting or restoring the environment;

(4) improving human health;

(5) promoting the arts, sciences, or advancement of knowledge;

(6) increasing the flow of capital to entities with a purpose to benefit society or the environment; and

(7) conferring any other particular benefit on society or the environment. 
Directors of US benefit corporations, in discharging their duties, are required to consider (or balance in Delaware) the impact of their decisions on shareholders and all the other stakeholders of the company (such as employees, customers, the community), the environment, and the achievement of the public benefit purpose. ${ }^{85}$

Transparency provisions require benefit corporations to publish an annual benefit report (every two years in Delaware) on their social and environmental impact using a comprehensive, credible, independent and transparent third-party standard (the third-party standard is not expressly required in Delaware). ${ }^{86}$

In the US, there is no public control over benefit corporations' reporting and activity. Should directors fail to pursue the public benefit purpose, the only available remedy is the benefit enforcement proceeding (or the ordinary shareholders derivative action in Delaware), the aim of which is not to recover monetary damages but to obtain an injunctive relief. ${ }^{87}$

As for the circulation of the legal model, Italy was the first state to follow the US example, enacting in 2015 a legislation regulating benefit corporations, the so-called 'società benefit' (SB). ${ }^{88}$ Later, between 2018 and 2020, benefit corporations were transplanted to several Latin American ${ }^{89}$ countries, such as Colombia, ${ }^{90}$ Ecuador $^{91}$ and Peru ${ }^{92}$ (the so-called 'Sociedades de Beneficio e Interés Colectivo'-BIC), and to British Columbia in Canada (i.e., the 'benefit company'). ${ }^{93}$ Moreover, in Europe, France introduced, in 2019, a new similar legal status, that of the 'entreprise à mission', amending the Civil Code and the Commercial Code in order to allow a company to incorporate social and environmental objectives into the corporate object clause. $^{94}$

Considering the substance of the legal transplants, the Italian 'for benefit' model was the first benefit corporation model implemented by a civil law system. It is a mix between the Model Act and the Delaware law but is characterised by some typical features. In particular, the major innovations, compared to the US model, are the scope of the legislation and the control systems.

\footnotetext{
85 Model Act $\S 301$.

86 Model Act $\$ \$ 401$ and 402.

87 Model Act $\$ 305$.

88 Law of 28 December 2015, n. 208 'Disposizioni per la formazione del bilancio annuale e pluriennale dello Stato (Legge di Stabilità 2016)’ (G.U. 30 December 2015), Art. 1, paras. 376-384.

89 On the issue see Alcalde Silva (2018), p 381 et seq.

90 Law No. 1901, of 8 June 2018.

91 See the Resolution of the Superintendencia de Compañías, Valores y Seguros No. SCVS-INCDNCDN-2019-0021, of 6 December 2019, and the Law of 7 January 2020 (the so-called 'Ley Orgánica de Emprendimiento e Innovación'), published in the Registro Oficial Suplemento No. 151, of 28 February 2020 .

92 Bill No. 2533/2017-CR, the so-called Ley de Sociedades de Beneficio e Interés Colectivo, was approved on 23 October 2020 by the Congreso de la República.

93 The Business Corporations Amendment Act (No. 2) 2019 (Bill M209), which introduced benefit companies in the Business Corporations Act (see Chapter 57, Part 2.3, §§ 51.991-51.995), received the Royal Assent on 16 May 2019 and entered into force on 30 June 2020.

94 Law No. 2019-486 of 22 May 2019, Art. 169.
} 
With regard to the first innovation, the società benefit status can be acquired by any existing for-profit and cooperative organisational form provided by the Civil Code. This approach has been followed by other civil law countries, such as Colombia, Ecuador, Peru and France, where the hybrid status (BIC or entreprise à mission) can be adopted by any existing for-profit organisational form (or cooperative company) provided by law.

As for the second innovation, the Italian system has provided for a public enforcement mechanism through the attribution of supervisory powers over the behaviour of società benefit to the Italian Competition Authority (Autorità Garante della Concorrenza e del Mercato). Again, the Italian approach has been followed by other civil law countries, such as Colombia, ${ }^{95}$ Ecuador, ${ }^{96}$ Peru $^{97}$ and France ${ }^{98}$ that decided to set up different public enforcement systems.

Finally, it is worth mentioning that with regard to tax treatment, none of the countries that have so far regulated benefit corporations have introduced specific tax advantages associated with the use of 'for-benefit' models, ${ }^{99}$ which are subject to the ordinary income tax rules provided for each organisational form. However, to facilitate the spread of the new models, some states have provided minor incentives, ${ }^{100}$ or advantages granted at local level or in public procurement procedures. ${ }^{101}$

\footnotetext{
95 In Colombia, oversight of BICs is assigned to the Superintendencia de Sociedades, an administrative body that maintains a public list of third-party standards to measure the BIC companies' impact and oversees their compliance with the law.

96 In Ecuador, supervisory powers regarding BIC companies have been assigned to the Superintendencia de Compañías, Valores y Seguros, which may sanction those companies that do not pursue the public benefit purposes or violate the rules regulating BIC companies.

97 The Peruvian system, which seems to be the one most inspired by the Italian model, has assigned supervisory powers regarding BICs to the Superintendencia Nacional de los Registros Públicos and to the national competition authority (Instituto Nacional de Defensa de la Competencia y de la Protección de la Propiedad Intelectual), which has the power, as in Italy, to sanction those companies which, by improperly using their status, perform acts that can be traced back to misleading advertising or other practices contrary to free competition and consumer protection.

98 In France, the public prosecutor, or any interested person (all stakeholders of the company), can start a claim to ask for the removal of the entreprise à mission status in case of violations of the applicable regulation or in case the social and environmental objectives are not respected (see French Commercial Code, Art. L. 210-11).

99 As far as Italy is concerned, it is important to stress that there is a debate among scholars and within the Italian Tax Authority (Agenzia delle Entrate) over the possible reduction (in accordance with the already existing law) of the company's taxable income with regard to all costs related to the pursuit of the public benefits provided for in the bylaws. On the issue see Setti (2016), pp 2303-2305.

100 In Colombia, see Decree No. 2046 (Diario Oficial N. 51135, 12 November 2019), which provides for special tax treatment of profits generated and distributed through the allocation of shares to employees, or preferential access to credit lines specifically created by the government. In Italy, see Art. 38-ter, Law 17 July 2020, No. 77 (the so-called 'Decreto Rilancio'), which provides for the recognition of a tax credit equal to $50 \%$ of the costs of incorporation of, or for the acquisition of the status of società benefit, and the establishment of a fund aimed at promoting the 'for benefit' model at the Ministry of Economic Development.

101 See, in Italy, the new reward criteria based on the positive impact of the company to be used in the evaluation of tenders in public procurement procedures, provided for by Art. 83, para. 10, and Art. 95, para. 13, of the 'Public Contract Code' ('Codice dei contratti pubblici', Legislative Decree No. 50, 18 April 2016), as amended by Art. 49, Law of 19 December 2019, No. 157.
} 
From this brief analysis based on the legal systems that have so far regulated the benefit corporation model it is possible to identify a convergence between civil law countries and to affirm that they have embraced some characteristics of the Italian model.

\section{The Benefit Corporation as the New Form of Firm Altruism}

What characterises the 'for benefit' models is that they allow the introduction of the so-called 'triple bottom line' approach (of 'people, planet and profit') into the corporate purpose clause. ${ }^{102}$

This means that, in order to have a positive impact on the environment and society and to create shared value, shareholders need to 'sacrifice' the 'maximisation of shareholder value' as the main purpose of the company, in particular in the short term.

Actually, conducting an economic activity in a sustainable way, on the one side, can generate profits attracting conscious consumers and increasing the company's reputational capital, but, on the other hand, can be more expensive. For instance, the implementation of sustainable production strategies can be more expensive compared to the application of strategies focused only on cost reduction; sharing value with employees reduces the amount of profits distributed to shareholders; involving disadvantaged people as employees can be more expensive, especially at the beginning due to their training, etc.

Thus, from the EAL perspective it is possible to affirm that the creation of a benefit corporation (or other similar hybrid models) seems to be contrary to the homo economicus paradigm because it represents a deviation from the rational choice and maximisation of shareholder value paradigm.

Would it therefore be irrational for entrepreneurs or shareholders to choose to cut their own personal profit with a view to adding value to the community, creating benefits for the environment and civil society?

Thus, when investigating the benefit corporation phenomenon from the corporate law perspective, there are two questions that need to be answered:

(i) Why should entrepreneurs or shareholders decide to relinquish part of their personal profit, reducing the profitability of the corporation in favour of production processes and entrepreneurial strategies oriented towards social and environmental sustainability? 'If not for profit, for what?' ${ }^{103}$ If not for profit (or

\footnotetext{
102 Elkington (1997). On this issue see also Fisk (2010); Slaper and Hall (2011), pp 4-8.

103 One of the main issues in the analysis of the regulations regarding the benefit corporation is summarised in the title of the well-known contribution of Young (1983), suggesting an interesting behavioural theory about the entrepreneurial non-profit sector.
} 
rather, for the maximisation of personal profit), for what other reason should one invest in a for-profit corporation?

(ii) How does the anthropological change of such entrepreneurs-who appear to be guided by a deeper ethos compared to the maximisation of profit in the short term ${ }^{104}$ and are willing to integrate altruistic values in the business strategy and organisation-affect corporate law, and in particular the corporate governance debate?

\subsection{If Not for Profit, for What?}

To answer the first question, the starting point cannot but be, then, an analysis aiming at understanding the underlying reasons that push an entrepreneur to use an organisational form characterised by a blended purpose, i.e., a selfish one (personal profit) and an altruistic one (public benefit), given the lack of specific tax advantages and considering the additional obligations and cost to achieve the public benefit results and disclose them which are imposed on benefit corporations. ${ }^{105}$

Using the arguments employed by Calabresi, the benefit corporation model, although apparently in contrast with the concept of 'maximising individual', is therefore made logical when considered as the product of a new way of interpreting economics, according to which the purposes-selfish (for profit-making) and altruistic (for the public benefit) — are both desired by the shareholders as goods in and of themselves. These purposes both enter into the company's charter and by-laws, legitimising the pursuit of business strategies that can turn out to be less profitable in terms of immediate profit and maximisation of wealth for the shareholder, ${ }^{106}$ but capable of generating wealth to be shared with the community and the environment.

The benefit corporation model must not be deemed irrational only because it does not respond to the McKean paradox and the pure market and command structures. In particular, with regard to market incentives, there is a lack of transactional gift, given the absence of tax benefits or any other kind of benefits for the new corporate model. While, considering the absence of any limits to remunerations, that is typical of not-for-profit organisations, there could be a chance for the rise of modified market incentives in the form of rewards to managers for results achieved in terms of profit and public benefit. ${ }^{107}$

Moreover, the introduction of benefit corporations' statutes represents a modified command structure stimulating firm altruism, in that it offers businesses the chance

\footnotetext{
$\overline{104}$ On this point Bazela et al. (2010), p 193.

105 In conformity with the trend in the US, the Italian legislator's choice not to grant, at least initially, tax advantages to the benefit corporation seems to be utterly consistent with the rationale underlying the legal doctrine intended to promote a new paradigm of business that is actually focused on prospects for long-term environmental and social sustainability, and it serves as a shield against improper use of the new model by corporations only aiming at gaining tax advantages.

106 For a summary of the several advantages, also economic, that a corporation can derive from a good reputation in terms of social and environmental sustainability see Monoriti and Ventura (2017), pp 11251128.

107 On the issue see Calabresi (2016), pp 105-107 and 110-111.
} 
to freely opt for the legal model of the benefit corporation without imposing altruism from above through a rigid system of prescriptions, thereby destroying it; rather, it indirectly induces altruism, thus contributing to the creation of an entrepreneurial culture that is attentive to the protection of the environment as well as of civil society $^{108}$.

Hence, if we look at the public benefit, as a good in and of itself, desired by shareholders, the benefit corporation model cannot be deemed irrational merely because it does not correspond to the behavioural model of the homo economicus.

\subsection{The Benefit Corporation in the Corporate Governance Debate}

Moving on to the second question, it is first of all necessary to stress that the benefit corporation represents a new governance model that exceeds philanthropy and corporate social responsibility. While corporate social responsibility, philanthropy, or the use of codes of ethics and self-regulation represent an obligation voluntarily undertaken by the company and therefore an external self-restraint limit as opposed to the dynamic of pure profit, ${ }^{109}$ the adoption of the benefit corporation model imposes an internal limit on the for-profit aim, rephrasing in environmental and social terms the guiding principles of directors' discretionary activity.

As regards corporate law, the introduction of benefit corporations allows, through a voluntary choice made by the founding shareholders or by the shareholders' general meeting, the internalisation-which is legally binding on both the corporation and the directors - of the typical values of corporate social responsibility within the corporate purpose clause. ${ }^{110}$

The formation of a corporation is the expression of the private autonomy of the shareholders (though within the limits of the mandatory rules prescribed by the law) who, opting for the new model characterised by a double purpose, decide to include in the articles of association the purpose of public benefit (general and/or specific, depending on the applicable state law). By so doing, the perimeter of the company's purpose is widened to include both purposes desired by the shareholders - 'for profit' and 'for benefit'-imposing an internal limit ${ }^{111}$ on the dynamic of maximisation of shareholders' wealth and, consequently, on the directors' management activity, which must be aimed at striking a balance between shareholders' for-profit interest, the public benefit and the interests of a vast audience of stakeholders.

It is precisely the voluntary inclusion of the public benefit purpose in the corporate purpose clause that characterises benefit corporations, thus allowing to place

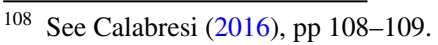

109 In this sense Montalenti (2010), p 99. See also Calandra Buonaura (2010), p 102; but also the observations of Denozza (2005), pp 19-20, on the idea that corporate accountability is better achievable through constraints externally imposed on the corporation, by the law, as opposed to the rephrasing in social terms of the criteria that must guide the discretionary action of the directors.

110 See Stella Richter (2010), pp 460-461.

111 On the regulation of negative externalities produced by corporate activity see Bainbridge (2003), p 586 et seq., who, for a complete synthesis of the scholarship on regulation theory, makes reference to Hertog (2000), p 223 et seq. See also Hertog (2010).
} 
them in the conceptual framework of contractarian theory and the shareholder primacy model.

Shareholders' decision to pursue the public benefit purpose (general and/or special), which is desired as a good in and of itself, on an equal footing with profit, determines a different 'characterisation of the interests sought by the very same shareholders ${ }^{112}$ : shareholders do not pursue third-party interests (stakeholders', community, or environment interests), rather it is their very interest as shareholders that is broadened to encompass both personal profit and the altruistic purpose of generating positive externalities or reducing negative ones deriving from the company's activity. ${ }^{113}$

Such expansion of the shareholders' interest does not stem from mandatory rules or the acceptance of a revived concession theory or communitarian perspective compelling the pursuit of some form of public benefit, but rather from the unbound expression of shareholders' autonomy. This implies the non-contradiction between the 'for benefit' model and the principles of liberal economy, since the internal limits to the shareholders' interest derive from shareholders' will, as opposed to being a restriction of their personal free will. ${ }^{114}$

From the corporate governance debate perspective, the new corporate model with a blended purpose cannot be considered either as part of the stakeholder theory ${ }^{115}$ or as part of the director primacy ${ }^{116}$ or the team production theory. ${ }^{117}$

According to Bainbridge,

[a]ny model of corporate governance must answer two basic sets of questions:

(1) Who decides? In other words, which corporate constituency possesses ultimate decisionmaking power? (2) When the ultimate decisionmaker, whoever it may be, is presented with a zero sum game in which it must prefer the interests of one corporate constituency over those of all others, whose interests prevail $?^{118}$

Following Bainbridge's theoretical framework, the two basic questions to be answered for the analysis of the benefit corporation governance model are: (1) who has the ultimate control of the corporation? (the means question); and (2) to what ends must this control be exercised? (the ends question).

\footnotetext{
112 The expression here employed, although with reference to a different field, is taken from Angelici (2010), p 47.

113 On the two-dimensional configuration ('declinazione bidimensionale') of shareholders' interests in a benefit corporation see Denozza and Stabilini (2017), pp 14-15.

114 Angelici (2010), p 55, raises the issue of the relationship between the importance of the stakeholders' interests and the liberal economy.

115 Freeman and Reed (1983), p 89 et seq.; Freeman (1984); Mitroff (1983). On the development of prostakeholder governance theory see Jonsen (2016), p 292 et seq.; Blair (1995); Kay (1997), pp 125-141; Kelly and Parkinson (1998), p 174 et seq.; Keay (2008), p 663 et seq.; Attenborough (2012), p 4 et seq.; Mayer (2013).

116 Bainbridge (2003), p 547 et seq.; Bainbridge (1993), p 1423 et seq.

117 Blair and Stout (1999), p 247 et seq.; Blair (1998), p 27 et seq.; Blair (2003), p 387 et seq.; Stout (2007), p 789 et seq.; Stout (2015), p 685 et seq.

118 Bainbridge (2003), p 605.
} 
As for the stakeholder theory, stakeholders should have the ultimate control, and the primary goal of the corporation should be the balancing of the interests of all the constituencies impacted by the corporation's activity. Benefit corporations cannot fall within the stakeholder theory in that:

(i) stakeholders do not take part in the control of the corporation; in fact, stakeholders have no right in the management, nor are they entitled to take action in case of directors' failure to pursue benefit purposes;

(ii) the pursued interest is that of the shareholders (although widened to include the safeguard of different stakeholders' interests and the achievement of the public benefit) and the directors bear fiduciary duties exclusively towards the shareholders.

As for the director primacy theory, the board of directors has the control, and the primary goal of the corporation is the shareholders' wealth maximisation. The benefit corporation model cannot fall within the director primacy model since:

(i) the control remains with the shareholders, who decide on the expansion of the corporate purpose (indicating its limits within the corporate purpose clause) and delegate to the directors the activity of balancing the pursued interests;

(ii) the aim is not that of shareholders' wealth maximisation, given that the shareholders' economic interest is mitigated by the public benefit purpose.

As for the team production theory, the board of directors, intended as 'mediating hierarchs', has the ultimate control of the corporation and the director's job is to balance team members' competing interests. Benefit corporations cannot fall within the team production theory considering that:

(i) the control still lies with the shareholders, since directors' obligation to mediate among the different interests is not enshrined in their role, rather it is conferred on them by the shareholders, including the public benefit purposes in the company agreement;

(ii) the aim pursued is not the abstract realisation (left to the directors' pure discretion) of efficient forms of collaboration, rather it is the legal obligation to look after shareholders' actual interest, as widened by the inclusion of the public benefit purposes in the company agreement.

Indeed, in benefit corporations corporate control lies with the shareholders (the 'means question') who then delegate it to the board of directors. The directors, as agents of the shareholders, must pursue their interests as established and widened in the company agreement (the 'ends question').

Compared to the shareholder primacy model, then, what is not accepted here is exclusively the primary purpose of maximisation of shareholder wealth, in that the shareholders themselves, within the range of their private ordering, have decided to impose a restriction thereon by also accepting purposes of public benefit. 
The above interpretation becomes evident from the shareholder-centric configuration of the benefit corporations law $^{119}$ in the US and other legal systems such as Italy.

To stakeholders other than the shareholders or, more generally, to the beneficiaries of the public benefit, neither the Italian nor the US legislation attributes any right to participate in the management of the corporation: there is no provision establishing a special assembly for them; they have no rights to vote in the general assembly, still wholly reserved to the shareholders; there is no provision on some kind of representation in the managing or control bodies, still exclusively appointed by the shareholders.

Furthermore, in both systems, the inclusion of public benefit purposes (general and specific) in the corporate purpose clause does not imply the creation of personal rights for third parties benefiting therefrom, nor does it imply the existence of any enforceable duty of directors to a person that is a beneficiary of the public benefit purpose or to other non-shareholder constituents. Indeed, the only fiduciary duties directors have are those owed to the corporation and its shareholders. ${ }^{120}$ Consequently, the only ones who are entitled to act in cases of breach in the implementation of public benefit purposes are the corporation and its shareholders. ${ }^{121}$ No action is expressly prescribed in favour of stakeholders. ${ }^{122}$

Even the procedures that are provided for an existing corporation to acquire the legal status of benefit corporation or to terminate its status as such emphasise the fundamental role of shareholders in that they prescribe the existence of a supermajority (so-called 'minimum status vote' in the US Model Act) in order to amend the articles of incorporation or approve a fundamental transaction such as a merger, consolidation or conversion. ${ }^{123}$

\footnotetext{
119 On the pivotal role of the shareholders and on the benefit corporation as a tool for the enhancement of shareholders-investors' autonomy, see Denozza and Stabilini (2017), p 10 et seq.

120 For the United States, see Model Act $§ 301$ (d); $§ 305$ (a); Del. Code Ann. tit. 8, § 365 (b). In Italy, through the reference (in the Law of 28 December 2015, n. 208 (G.U. 30.12.2015), Art. 1, para. 381) to the directors' liability actions set forth in the Civil Code for each type of corporation, the legislator seems to deny the existence of additional duties and responsibilities of directors with regard to third parties that benefit from the public benefit and that remain devoid of direct protection, except for the action stemming from Arts. 2395 and 2476, para. $6^{\circ}$, c.c., as long as the preconditions established by law are met. On the non-contractual action that can be brought by third parties and single shareholders see Corso (2016), p 1025; Riolfo (2016), pp 729-730.

121 Model Act $\S 305$ (b); Del. Code Ann. tit. 8, § 367; Law of 28 December 2015, n. 208 (G.U. 30.12.2015), Art. 1, para. 381.

122 With regard to the US, there was an exception in a provision initially included in the US. Model Act which allowed the right of action for those specifically listed in the deed of incorporation; however, this provision was removed in 2016 and was rarely implemented by state legislatures, see Model Act $2014 \S$ 305 (c)(2)(iv); the provision was not included in the last version of the Model Act, of 2017.

123 The Model Act ( $\S 102,104$ and 105-'Minimum status vote') prescribes a two third majority of the shareholders with voting rights in each category or class of shares to modify the bylaws converting an ordinary corporation into a benefit corporation or, conversely, a benefit corporation into an ordinary business corporation. In contrast, Delaware amended the Public Benefit Corporation Statute (Del. Code Ann. tit. 8, Ch 1, Subchapter XV) in July 2020, reducing the stockholder approval threshold necessary for becoming a PBC and for exiting the PBC regime. Section 363(a) and (c) has been eliminated and the voting thresholds for conversions, mergers and consolidations involving PBCs are now governed by the ordinary rules of the Delaware General Corporation Law (\$§ 242(b) and 251) that prescribe majority vot-
} 
Lastly, the lack of governmental powers of control over the activity performed by benefit corporations should be stressed. In the US, the only form of control is through private enforcement tools such as the benefit enforcement proceeding or shareholders derivative actions for breach of fiduciary duties and disclosure mechanisms (annual report and free employment of the third-party standard). This private enforcement regime has been established in favour of shareholders and third parties (customers and investors who have access to information) and not with a view to allowing any form of public control. ${ }^{124}$ In Italy, the supervisory role attributed to the Public Competition Authority does not impact on the above analysis, in that the Authority operates on a level other than corporate law, considering the violation of external limits imposed on corporations by the regulation aimed at safeguarding competition and consumers. ${ }^{125}$

Taking into account the graphic representation proposed by Bainbridge, ${ }^{126}$ it is possible to summarise what has been described to this point by placing the 'for benefit' corporation in Fig. 1.

On the Means Axis (who has the ultimate control of the corporation) are the theories that emphasise, on the one hand, the role of the board of directors and, on the other, the role of the shareholders. On the Ends Axis (to what ends must this control be exercised) are, instead, theories that emphasise, on the one hand, shareholder wealth maximisation, meant as an exclusively economic value represented by the maximisation of the shares' market value, and, on the other, the stakeholder model, according to which the management aims at equally safeguarding the various interests carried by all the existing corporate constituencies.

Benefit corporations are to be placed, with regard to the control in the area of shareholder primacy, considering the shareholder-centric regulation and regarding the interests pursued, in an intermediate area that can be defined as 'shareholder welfare maximisation' (wealth + altruism), which suggests that the pursuit of the shareholders' interests includes: on the one hand, the shareholders' economic interest (i.e., wealth, but without the aim of its maximisation in monetary terms), and, on

\footnotetext{
Footnote 123 (continued)

ing unless the certificate of incorporation provides otherwise. Moreover, the 2020 amendment also eliminates statutory appraisal rights in connection with the conversion of a corporation to a PBC ( $\$ 363(\mathrm{~b})$ ). As regards Italian law, it is necessary to have all shareholders' consent in case of società di persone (i.e., partnerships, Art. 2252 c.c.). In società per azioni (i.e., corporations), given the competence of the extraordinary shareholders' meeting to decide on amendment to the corporate purpose (Arts. 2365, 2368 ICC), supermajorities are required, with a quorum beyond one third of the share capital (Art. 2369, para. 5 , ICC) and a quorum of two thirds of the capital represented in the assembly for listed corporations (2369, para. 3, ICC). In società a responsabilità limitata (i.e., limited liability companies) amendment of the deed of incorporation is left to the shareholders assembly (Arts. 2479, para. $2^{\circ}$, nn. 4 and 5, and 2480 ICC) deciding with the favourable vote of shareholders representing at least half of the share capital (Art. 2479-bis, para. $3^{\circ}$ ICC).

124 The choice of the evaluation standards is left to the corporation and there is no prescription concerning a check by third parties, either private or public, Model Act $\S 401$ (c); Del. Code Ann. tit. 8, § 366(c) (3); Law of 28 December 2015, n. 208 (G.U. 30.12.2015), Art. 1, para. 382.

125 See Law of 28 December 2015, n. 208 (G.U. 30.12.2015), Art. 1, para. 384.

126 Bainbridge (2003), p 548.
} 


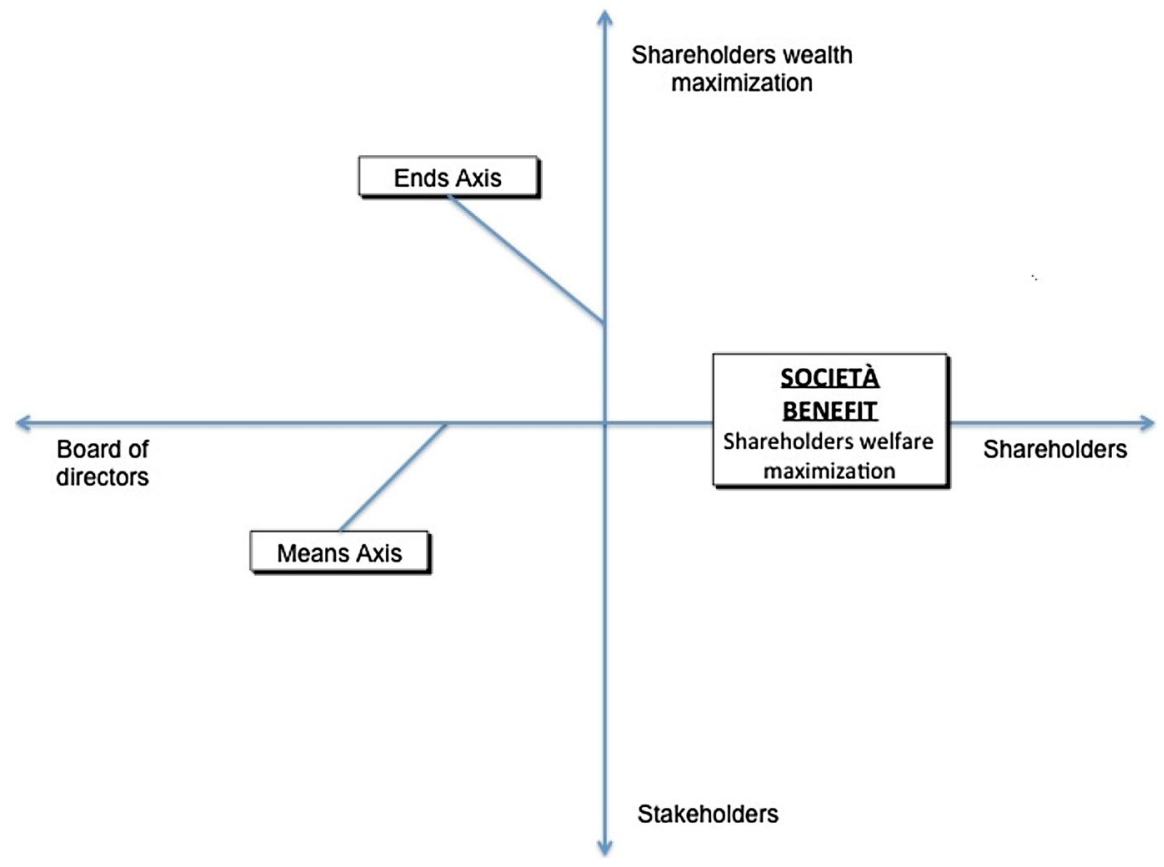

Fig. 1 The 'for benefit' model within the corporate governance debate

the other hand, other 'altruistic' values, such as the purpose of public benefit, both general and special (i.e., altruism). ${ }^{127}$

\section{Conclusions}

Using the categories employed by Calabresi, it can be affirmed that benefit corporations constitute a further manifestation of firm altruism, more efficient (from a law perspective) than not-for-profit organisations, in that it is devoid of the limits of the non-distribution constraint - which prohibits the distribution of residual earnings to individuals who exercise control over the firm-and is characterised, compared to philanthropy, by a deeper and lasting impact on the environment and civil society, given the integration of altruistic values within the framework of the business purpose clause contained in the articles and memorandum of association.

Moreover, the use of the benefit corporation model as a vehicle for firm altruism falls outside the debate over the relationship between philanthropic activity and shareholder wealth, or the larger debate over the link between corporate social

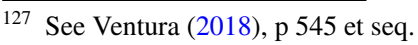


responsibility and corporate financial performance ${ }^{128}$ given that the shareholder wealth maximisation paradigm is attenuated in favour of the shareholder welfare maximisation paradigm.

If we look at the law as a tool capable of shaping social awareness and at the same time as an expression of the internal dynamics of civil society, of its social and economic values, ${ }^{129}$ it is possible to assess, on the one hand, how the introduction of benefit corporations' statutes contributes to creating a new culture of altruism, educating entrepreneurs, consumers and investors in a new form of capitalism (stakeholder capitalism), and, on the other hand, how it corresponds to the cultural transformation currently happening in civil society and supports the growing collective desire for firm altruism.

Finally, from the European perspective, the legal transplant of the US benefit corporation hybrid model would be consistent with the recent European Union initiatives - such as the proposal for a directive on directors' duties and sustainable corporate governance-recognising the growing importance of sustainability in the business sector and aimed at a more comprehensive protection of stakeholders' interests in for-profit entities.

\section{References}

Alcalde Silva J (2018) Observaciones a un nuevo proyecto de ley que regula las empresas de beneficio e interés colectivo desde la experiencia comparada. Revista Chilena De Derecho Privado 31:381-425

Alpa G (2016) Il futuro di law and economics: le proposte di Guido Calabresi. Contr e Impr 32:597-607

Angelici C (2010) La società per azioni e gli 'altri.' In: Sacchi R (ed) L'interesse sociale tra valorizzazione del capitale e protezione degli stakeholders. In ricordo di Pier Giusto Jaeger. Giuffré, Milan, pp 45-62

Angelici C (2018) Società benefit. In: De Donno B, Ventura L (eds) Dalla benefit corporation alla società benefit. Cacucci, Bari, pp 19-32

Attenborough D (2012) Giving purpose to the corporate purpose debate: an equitable maximisation and viability principle. Leg Stud 32:4-34

\footnotetext{
128 On the issue see, among others, Godfrey (2005), p 777 et seq.; and Liang and Renneboog (2017), p 278 et seq.

129 See Calabresi (2016), p 157 et seq., who, affirms the centrality of the legislator and the law (or of the jurisprudence in the common law countries) in shaping values typical of a given community, and therefore the existence of a relationship between law and values. To reach this conclusion, the author draws inspiration from the influence of some decisions rendered by the Supreme Court of the United States and other State supreme courts, pointing out that the amendments on the legislative or jurisprudential level can pave the way for a change in the values of the community (Plessy v. Ferguson, 63 US 537 (1896); Brown v. Bd of Ed. of Topeka, 347 US 483 (1954); Dred Scott v. Sandford, 60 US 393 (1857)) just as much as for the rise of counter-movements that are stronger than the legislative amendment (Goodridge v. Dept. of Public Health, 440 Mass. 309 (2003); Roe v. Wade, 410 US 113 (1973)). On the integration between law and other social and cultural phenomena, see the essay on the movement of the Critical Legal Studies by Minda (1st edn 1995, Italian trans. 2001), pp 180, 189, 199; and Gambaro and Sacco (2008), p 18. See also Bruni and Zamagni (2015), pp 42-43, for a reference to the relationship between rules and values and éthos of a population; and Denozza (2005), p 20, for a reference to the interaction between demand for corporate responsibility coming from civil society and the public initiative aimed at increasing Queryawareness of the issue of corporations.
} 
Bainbridge SM (1993) In defense of the shareholder wealth maximization norm: a replay to Professor Green. Wash Lee Law Rev 50:1423-1447

Bainbridge SM (2003) Director primacy: the means and ends of corporate governance. NW Univ Law Rev 97:547-606

Batson CD, Ahmad N, Stocks EL (2011) Four forms of prosocial motivation: egoism, altruism, collectivism, and principlism. In: Dunning D (ed) Social motivation. Psychology Press, New York, pp $103-126$

Bazela M (2010) Il fondamento antropologico per una società più sostenibile e le sue derivazioni etiche ed economiche. In: De Luca V et al (eds) Capitalismo prossimo venture-etica, regole, prassi. Egea, Milan, pp 182-192

Bebchuk LA (2003) The case for shareholder access to the ballot. Bus Law 59:43-66

Bebchuk LA (2005) The case for increasing shareholder power. Harv Law Rev 118:833-914

Bebchuk LA (2006) Reply: letting shareholders set the rules. Harv Law Rev 119:1784-1813

Bebchuk LA, Fried J (2004) Pay without performance: the unfulfilled promise of executive compensation. Harvard University Press, Cambridge

Bebchuk LA, Fried J (2005) Pay without performance: overview of the issues. J Corp L 30:647-673

Bebchuk LA, Fried J (2006) Pay without performance: overview of the issues. Acad Manag Perspect 20:5-24

Bebchuk LA, Tallarita R (2020) The illusory promise of stakeholder governance. Cornell Law Rev 106:91-178

Benedict XVI P (2009) Caritas in veritate. Libreria Editrice Vaticana, Città del Vaticano

Berle AA (1931) Corporate powers as powers in trust. Harv Law Rev 44:1049-1074

Berle AA (1932) For whom corporate managers are trustees: a note. Harv Law Rev 45:1365-1372

Berle AA (1954) The 20th century capitalist revolution. Harcourt Brace Jovanovich, New York

Berle AA (1959) Foreword. In: Mason ES (ed) The corporation in modern society. Harvard University Press, Cambridge, pp i-Xv

Berle AA, Means GC (1932) The modern corporation and private property. The Macmillan Company, New York

Blair MM (1995) Ownership and control: rethinking corporate governance for the twenty-first century. Brookings, Washington, D.C.

Blair MM (1998) A contractarian defense of corporate philanthropy. Stetson Law Rev 28:27-49

Blair MM (2003) Locking in capital: what corporate law achieved for business organizers in the nineteenth century. UCLA Law Rev 51:387-455

Blair MM, Stout LA (1999) A team production theory of corporate law. VA Law Rev 85:247-328

Bratton WW, Wachter ML (2008) Shareholder primacy's corporatist origins: Adolf Berle and the modern corporation. J Corp Law 34:99-152

Bruni L (2009) L'impresa civile — una via italiana all'economia di mercato. EGEA, Milan

Bruni L, Zamagni S (2015) L'economia civile. Il Mulino, Bologna

Calabresi G (2016) The future of law and economics. Essay in reform and recollection. Yale University Press, New Haven

Calandra Buonaura V (2010) Funzione amministrativa e interesse sociale. In: Sacchi R (ed) L'interesse sociale tra valorizzazione del capitale e protezione degli stakeholders. In ricordo di Pier Giusto Jaeger. Giuffré, Milano, pp 101-114

Carroll AB (1979) A three-dimensional conceptual model of corporate social performance. Acad Manag Rev 4:497-505

Carroll AB (1991) The pyramid of corporate social responsibility: toward the moral management of organizational stakeholders. Bus Horiz 34:39-48

Clemente M (2013) Benefit corporations: novelty, niche, or revolution. https://ssrn.com/abstract=23592 26. Accessed 27 Oct 2021

Coase RH (1937) The nature of the firm. Economica 4:386-405

Collison D, Cross S, Ferguson J, Power D, Stevenson L (2014) Financialization and company law: a study of the UK Company law review. Crit Perspect Acc 25:5-16

Corso S (2016) Le società benefit nell'ordinamento italiano: una nuova 'qualifica' tra profit e non-profit. Nuove Leggi Civ Commun 39:995-1031

DeBow ME, Lee DR (1993) Shareholders, nonshareholders and corporate law: communitarianism and resource allocation. Del J Corp Law 18:393-424

De Donno B, Ventura L (2018) Dalla benefit corporation alla società benefit. Cacucci, Bari 
De Luca V, Fitoussi JP, McCormick R (2010) Capitalismo prossimo venture-Etica, regole, prassi. Egea, Milan

Denozza F (2005) L'interesse della società e la responsabilità sociale d'impresa. Bancaria 61:18

Denozza F (2014) La frammentazione del soggetto nel pensiero giuridico tardo-liberale. Rivista Del Diritto Commerciale e Del Diritto Generale Delle Obbligazioni 112:13-47

Denozza F (2018) La società benefit e le preferenze degli investitori. In: De Donno B, Ventura L (eds) Dalla benefit corporation alla società benefit. Cacucci, Bari, pp 33-48

Denozza F, Stabilini A (2017) Due visioni della responsabilità sociale d'impresa, con una applicazione alla società benefit. https://webcache.googleusercontent.com/search?q=cache:QbtDGyFKtTYJ: https://core.ac.uk/download/pdf/187974683.pdf $+\& c d=2 \& h l=i t \& c t=c l n k \& g l=i t \& c l i e n t=$ firefoxb-d. Accessed 27 Oct 2021

Dodd EM (1932) For whom are corporate managers trustees? Harv Law Rev 45:1145-1163

Dovidio JF, Piliavin JA, Schroeder DA, Penner L (2006) The social psychology of prosocial behavior. Lawrence Erlbaum, Mahwah

Elkington J (1997) Cannibals with forks: the triple bottom line of 21st century business. Capstone, Oxford

Fehr E, Fischbacher U (2003) The nature of human altruism. Nature 425:785-791

Fehr E, Gächter S (2000a) Fairness and retaliation: the economics of reciprocity. J Econ Perspect 14:59-181

Fehr E, Gächter S (2000b) Cooperation and punishment in public goods experiments. Am Econ Rev 90:980-994

Fehr E, Schmidt KM (2006) The economics of fairness, reciprocity and altruism. Experimental evidence and new theories. In: Kolm S-C, Ythier JM (eds) Handbook of the economics of giving, altruism and reciprocity, vol 1. Elsevier, Amsterdam, pp 615-691

Fisk P (2010) People, planet, profit: how to embrace sustainability for innovation and business growth. Kogan Page Ltd, London

Francis P (2015) Laudato sì. Enciclica sulla cura della casa comune. Libreria Editrice Vaticana, Città del Vaticano

Freeman RE (1984) Strategic management: a stakeholder approach. Cambridge University Press, Cambridge

Freeman RE, Reed DL (1983) Stockholders and stakeholders: a new perspective on corporate governance. Calif Manag Rev 25:88-106

Friedman M (1953) Essays in positive economics. University of Chicago Press, Chicago

Friedman M (1970) The social responsibility of business is to increase its profits. The New York Times Magazine

Gambaro A, Sacco R (2008) Sistemi giuridici comparati, 3rd edn. UTET, Turin

Gentili A (2014) Il ruolo della razionalità cognitiva nelle invalidità negoziali. In: Rojas Elgueta G, Vardi $\mathrm{N}$ (eds) Oltre il soggetto razionale-fallimenti cognitivi e razionalità limitata nel diritto privato. Roma Tre Press, Rome, pp 75-102

Gintis H, Bowles S, Boyd R, Fehr E (2003) Explaining altruistic behavior in humans. Evol Hum Behav 24:153-172

Godfrey PC (2005) The relationship between corporate philanthropy and shareholder wealth: a risk management perspective. Acad Manag Rev 30:777-798

Grant JK (2012) When making money and making a sustainable and societal difference collide: will benefit corporations succeed or fail? Ind Law Rev 46:581-602

Hansmann H (1980) The role of nonprofit enterprise. Yale Law J 89:835-901

Hansmann H (1981) Reforming nonprofit corporations law. Univ PA Law Rev 129:497-623

Hansmann H, Kraakman R (2001) The end of history for corporate law. Geo Law J 89:439-468

Hargreaves Heap S, Varoufakis Y (1995) Game theory. A critical introduction. Routledge, London

Harwell Wells CA (2002) The cycles of corporate social responsibility: an historical retrospective for the twenty-first century. Univ Kan Law Rev 51:77-140

Hertog JD (2000) General theories of regulation. In: Bouckaert B, De Geest G (eds) Encyclopedia of law and economics. The regulation of contracts, vol III. Edward Elgar, Cheltenham, pp 223-270

Hertog JD (2010) Review of economic theories of regulation. Tjalling C. Koopmans Research Institute, Discussion Paper Series 10-18. https://www.uu.nl/sites/default/files/rebo_use_dp_2010_10-18.pdf. Accessed 27 Oct 2021

Jackson KT (2010) Global corporate governance: soft law and reputational accountability. Brook J Int Law 35:41-106 
Jonsen RH (2016) Other-constituency theories and firm governance: is the benefit corporation sufficient? J Manag Spirit Relig 13:288-303

Kahneman D (2011) Thinking, fast and slow. Penguin, London

Kahneman D, Tversky A (1974) Judgement under uncertainty: heuristics and biases. Sci New Ser 185:1124-1131

Kahneman D, Tversky A (1984) Choice, values, and frames. Am Psychol 39:341-350

Kay J (1997) The stakeholder corporation. In: Kelly D et al. (eds) Stakeholder capitalism. Palgrave Macmillan, London, pp 125-141

Keay A (2008) Ascertaining the corporate objective: an entity maximisation and sustainability model. Mod Law Rev 71:663-698

Kelly G, Parkinson J (1998) The conceptual foundations of the company: a pluralist approach. Co Financ Insolv Law Rev 2:174-197

Kerr JE (2008) The creative capitalism spectrum: evaluating corporate social responsibility through a legal lens. Temp Law Rev 81:831-870

Khalil EL (2001) Adam Smith and three theories of altruism. Recherches économiques de Louvain 67:421-435

Korobkin RB, Ulen TS (2000) Law and behavioral science: removing the rationality assumption from law and economics. Calif Law Rev 88:1051-1144

Liang H, Renneboog L (2017) Corporate donations and shareholder value. Oxf Rev Econ Policy 33:278-316

Lund DS, Pollman E (2021) The corporate governance machine. European Corporate Governance Institute, Law Working Paper $\mathrm{N}^{\circ}$ 564/2021. https://ssrn.com/abstract=3775846. Accessed 27 Oct 2021

Marasà G (2018) Scopo di lucro e scopo di beneficio comune nelle società benefit. In: De Donno B, Ventura L (eds) Dalla benefit corporation alla società benefit. Cacucci, Bari, pp 49-58

Mayer C (2013) Firm commitment. Oxford University Press, Oxford

Mayer C (2017) Who's responsible for irresponsible business? An assessment. Oxf Rev Econ Policy 33:157-175

Mayer C (2018) Prosperity. Better business makes the greater good. Oxford University Press, Oxford

McKean RN (1975) Economics of trust, altruism, and corporate responsibility. In: Phelps ES (ed) Altruism, morality, and economic theory. Russell Sage Foundation, New York

Millon D (1993) New directions in corporate law, communitarians, contractarians, and the crisis in corporate law. Wash Lee Law Rev 50:1373-1393

Minda G (1st edn 1995, Italian trans. 2001) Postmodern legal movements. Law and jurisprudence at century's end. New York University Press, New York. Italian trans. Colli C.Il Mulino, Bologna

Mitroff II (1983) Stakeholders of the organizational mind. Jossey-Bass

Monoriti A, Ventura L (2017) La società benefit: la nuova dimensione dell'impresa italiana. La Rivista nel Diritto 7:1125-1128

Montalenti P (2010) Interesse sociale e amministratori. In: Sacchi R (ed) L'interesse sociale tra valorizzazione del capitale e protezione degli stakeholders. In ricordo di Pier Giusto Jaeger. Giuffré, Milan, pp 81-100

Montgomery DB, Ramus CA (2007) Including corporate social responsibility, environmental sustainability, and ethics in calibrating MBA job preferences. Stanford University Graduate School of Business Research Paper No. 1981, http://ssrn.com/abstract=1077439. Accessed 27 Oct 2021

Parisi F, Smith VL (2005) The law and economics of irrational behavior. Stanford University Press, Stanford

Penner LA, Dovidio JF, Piliavin JA, Schroeder DA (2005) Prosocial behavior: multilevel perspectives. Ann Rev Psychol 56:365-392

Portale GB (2007) Lezioni di diritto privato comparato. Giappichelli, Turin

Posner RA (1998) Economic analysis of law, 5th edn. Aspen Law \& Business, New York

Reints R (2019) Consumers say they want more sustainable products. Now they have the receipts to prove it. In: Fortune, 5 November 2019. https://fortune.com/2019/11/05/sustainability-marketing-consu mer-spending/?utm_source=email\&utm_medium=newsletter\&utm_campaign=business-by-desig n\&utm_content=2019110520pm. Accessed 27 Oct 2021

Resta G (2014) Gratuità e solidarietà: fondamenti emotivi e 'irrazionali'. In: Rojas Elgueta G, Vardi N (eds) Oltre il soggetto razionale. Fallimenti cognitivi e razionalità limitata nel diritto privato. Roma Tre Press, Rome, pp 121-161

Riolfo G (2016) Le società 'benefit' in Italia: prime riflessioni su una recente innovazione legislativa. Studium Iuris 2016/6:720-730 and 2016/7-8:819-825 
Rock EB (2020) For whom is the corporation managed in 2020?: the debate over corporate purpose. European Corporate Governance Institute, Law Working Paper N ${ }^{\circ}$ 515/2020, https://ssrn.com/abstr act $=3589951$. Accessed 27 Oct 2021

Roe MJ, Spamann H, Fried JM, Wang CCY (2020) The European Commission's sustainable corporate governance report: a critique. European Corporate Governance Institute, Law Working Paper 553/2020, Harvard Public Law Working Paper No. 20-30. https://ssrn.com/abstract=3711652. Accessed 27 Oct 2021

Setti M (2016) Implicazioni fiscali del nuovo istituto delle società benefit. Corriere Tributario 2016(29):2301-2306

Shavell S (2004) Foundations of economics analysis of law. Harvard University Press, Cambridge

Simon HA (1955) A behavioral model of rational choice. Quart J Econ 69:99-118

Simon HA (1957) Models of man: social and rational. Wiley, New York

Slaper TF, Hall TJ (2011) Triple bottom line: what is it and how does it work? Ind Bus Rev 86:4-8

Smith A (1759) The theory of moral sentiments. A. Millar and A. Kincaid and J. Bell, London

Solomon RC (1998) The moral psychology of business: care and compassion in the corporation. Bus Ethics Q 8:515-533

Sommer AA Jr (1991) Who should the corporation serve? The Berle-Dodd debate revisited sixty years later. Del J Corp Law 16:33-56

Stella Richter M (2010) A proposito di interesse sociale e governo dell'impresa in Europa. In: De Luca V et al. (eds) Capitalismo prossimo venture-etica, regole, prassi. Egea, Milan, pp 454-465

Stella Richter M (2018) Società benefit e società non benefit. In: De Donno B, Ventura L (eds) Dalla benefit corporation alla società benefit. Cacucci, Bari, pp 59-70

Stout LA (2007) The mythical benefits of shareholder control. VA Law Rev 93:789-809

Stout LA (2014) Law and prosocial behavior. The Oxford handbook of behavioral economics and the law. Oxford University Press, Oxford

Stout LA (2015) The corporation as a time machine: intergenerational equity, intergenerational efficiency, and the corporate form. Seattle Univ Law Rev 38:685-723

Sunstein CR (1997) Behavioral analysis of law. Univ Chic Law Rev 64:1175-1195

Sunstein CR, Jolls C, Thaler RH (1998) A behavioral approach to law and economics. Stan Law Rev 50:1471-1550

Sustain CR (2000) Behavioral law and economics. Cambridge University Press, Cambridge

Thaler RH (1996) Doing economics without homo economicus. In: Medema SG, Samuels WJ (eds) Foundations of research in economics: how do economists do economics? Elgar, Cheltenham, pp 227-237

Thaler RH, Sunstein CR (2008) Nudge: improving decisions about health, wealth, and happiness. Yale University Press, New Haven

Toffoletto A (2015) Note minime a margine di Laudato sì. Società 11:1203-1209

Ulen TS (2000) Rational choice theory in law and economics. In: Bockaert B, De Geest G (eds) Encyclopedia of law and economics, pp 790-818

Ventura L (2018) 'If not for profit, for what?' Dall'altruismo come 'bene in sé' alla tutela degli stakeholder nelle società lucrative. Rivista del diritto commerciale e del diritto generale delle obbligazioni 3:545-590

Whelan T, Kronthal-Sacco R (2019) Research: actually, consumers do buy sustainable products. In: Harvard Business Review, 19 June 2019. https://hbr.org/2019/06/research-actually-consumers-do-buysustainable-products. Accessed 27 Oct 2021

Williston S (1888) History of the law of business corporations before 1800. Harv Law Rev 2:105-124

Young DR (1983) If not for profit, for what? A behavioural theory of the nonprofit sector based on entrepreneurship. Lexington Books, Lexington

Zamagni S (2013) Impresa responsabile e mercato civile. Il Mulino, Bologna

Zamir E, Teichman D (2014) The Oxford handbook of behavioral economics and the law. Oxford

Zoppini A (2016) Le domande che ci propone l'economia comportamentale ovvero il crepuscolo del 'buon padre di famiglia'. In: Rojas Elgueta G, Vardi N (eds) Oltre il soggetto razionale. Fallimenti cognitivi e razionalità limitata nel diritto privato. Roma Tre Press, Rome, pp 11-22

Publisher's Note Springer Nature remains neutral with regard to jurisdictional claims in published maps and institutional affiliations. 


\section{Authors and Affiliations}

\section{Livia Ventura ${ }^{1,2,3,4}$}

1 Ph.D. in Comparative and Uniform Business Law, Sapienza University of Rome, Rome, Italy

2 S.J.D., Temple University Beasley School of Law, Philadelphia, USA

3 Present Address: Adjunct Professor of Private Comparative Law at LUISS Guido Carli Law School, Rome, Italy

4 Academic Fellow at the Geneva Centre for Philanthropy, Geneva, Switzerland 